\title{
Changes in teat parameters caused by milking and their recovery to their initial size
}

\author{
LUDĚK STÁDNÍK', FRANTIŠEK LOUDA', JIŘÍ BEZDÍČEK², ALENA JEŽKOVÁ' and MICHAL \\ RÁKOS'
}

'Department of Animal Husbandry, Faculty of Agrobiology, Food and Natural Resources, Czech University of Life Sciences Prague, Prague, Czech Republic, ${ }^{2}$ Research Institute for Cattle Breeding, Ltd., Rapotín, Czech Republic

\section{Abstract}

Dairy cows of 2 breeds, 74 Holstein $(H)$ and 72 Czech Fleckvieh (C) cows in the $1 s t(H, n=38$; $C, n=38)$ and 2 nd lactation $(H, n=36 ; C, n=34)$ during the 1st period $(n=74 ; H, n=40 ; C, n=34$; to 150 days) and the 2 nd period of lactation ( $n=72 ; H, n=34 ; C, n=38$; above 150 days) were observed. Differences in external and internal proportions of teat closely before (the 1st measurement), immediately after (the 2nd measurement) and $3 \mathrm{~h}$ after milking (the $3 \mathrm{rd}$ measurement), udder conformation evaluated by linear description, somatic cell count, daily milk yield and the time of milking were evaluated in relation to the effect of breed and period of lactation. The length of the teat canal, area of the teat end, and wall thickness were measured from the axial picture recorded by ultrasound Aloka SSD500 (Aloka Co., Ltd., Tokyo, Japan).

Significant interbreed differences were detected in external as well as internal teat proportions $(P<0.05-0.001)$. Relative changes of teat diameter, comparing $\mathrm{C}$ and $\mathrm{H}$ cows, differed significantly between the 1 st and the 3 rd measurement $(P<0.05)$. The length of teat increased during milking and didn't achieve the beginning size during $3 \mathrm{~h}$ after milking. Significant diiference in the length of teat between the 2 nd measurement and the $3 \mathrm{rd}$ measurement was determined in $\mathrm{H}$ cows only $(P<0.001)$. The most significant changes of the length of the teat canal and the area of teat were found in both breeds between values measured closely before and immediately after milking $(P<0.5-0.001)$. Wall thickness was strengthen in $C$ cows $(+15.6 \%)$ during the 2 nd measurement according to the $1 s t(P<0.05)$, while difference represented $+18 \%(P<0.001)$ in $\mathrm{H}$ cows. Non-significantly higher values of external proportions of teat were measured in the 2 nd period of lactation except diameter of teat closely before milking. Internal proportions of teat were always significantly higher in the 2nd period of lactation in relation to the 1st period. Prolongation of teat canal by $0.15 \mathrm{~cm}$ $(P<0.01)$ closely before, by $0.16 \mathrm{~cm}(P<0.001)$ immediately after, and by $0.13 \mathrm{~cm}(P<0.01) 3 \mathrm{~h}$ after milking was measured in the 2 nd period of lactation. The area of teat end measured before milking was significantly larger in the 2 nd period of lactation $(P<0.01)$.

Keywords: cattle, internal proportions, external proportions, teat, ultrasound, period of lactation 


\section{Zusammenfassung}

\section{Veränderungen von Zitzenparametern durch das Melken und deren Rückbildung auf die Ausgangswerte}

Es wurden die Zitzenmaße bei 74 Holstein $(\mathrm{H})$ und 72 Tschechischen Fleckviehkühen $(\mathrm{C})$ in der ersten bzw. zweiten Laktation $(H, n=38 / 38, C, n=36 / 34$; im ersten Teil der Laktation bis 150 Tage $\mathrm{H}, \mathrm{n}=40$ und $\mathrm{C}, \mathrm{n}=34$ sowie im zweiten Teil nach 150 Tagen $\mathrm{H}, \mathrm{n}=34$ und $\mathrm{C}, \mathrm{n}=38$ ) erfasst. Verglichen wurden die Zitzenparameter vor, unmittelbar nach und drei Stunden nach dem Melken beider Rassen mit den Merkmalen Zitzenmaße, Zellzahl, tägliche Milchleistung und Melkbarkeit in den einzelnen Laktationsphasen. Die Messung der Zitzenkanallänge, der Zitzenfläche sowie der Wanddicke erfolgte mittels Ultraschall (Aloka SSD500 - Aloka Co., LTD, Tokyo, Japan). Zwischen den Rassen ergaben sich signifikante Differenzen sowohl bei den internen als auch externen Zitzenproportionen. Signifikante Unterschiede traten sowohl bei den Wanddicken als auch der Zitzenkanallänge vor bzw. drei Stunden nach dem Melken auf. Die Zitzenlänge vergrößerte sich und hatte auch drei Stunden nach dem Melken noch nicht den Ausgangswert erreicht. Bei beiden Rassen fanden sich hochsignifikante Veränderungen bei der Länge des Zitzenkanals und den Zitzenendflächen vor bzw. unmittelbar nach dem Melken. Die Ausweitung der Zitzenwanddicke gemessen mit Ultraschall direkt nach dem Melken betrug bei H 15,6\% bzw. 18,0\% bei C. In der zweiten Laktationshälfte wurden außer dem Zitzendurchmesser keine signifikant höheren Werte der externen Parameter ermittelt. In der zweiten Laktationshälfte betrug die Verlängerung des Zitzenkanals $0,15 \mathrm{~cm}$ kurz vor dem Melken, $0,16 \mathrm{~cm}$ unmittelbar nach und 0,13 cm drei Stunden nach dem Melken. Die Zitzenendfläche gemessen vor dem Melken war in der zweiten Laktationshälfte signifikant größer.

Schlüsselwörter: Rind, Interne Euterparameter, externe Euterparameter, Zitzen, Ultraschall, Laktationsphasen

\section{Introduction}

Milking, preparation of the mammary gland, technology of milking, and care of the udder represent a set of technical operations which significantly affect the quality of milk, health, and economics of a herd. The implementation of machine milking simplified the care of animals and increased milk quality, but on the other hand induced many disorders of udder (TWARDON et al. 2001). Changes in the physiological status of teat tissue can be evoked by technology or frequency of milking and increases the risk of infection to the udder (IPEMA and BENDERS 1992). The basic function of the teat is to hold and subsequently to give milk from the udder and at the same time to act as a barrier against possible infiltration of infection to the udder. It is necessary to rate the teat canal as one of the most important barriers against the intrusion of microorganisms into the udder. A vacuum in the teat extender opens teat canal and milk can flow out, but this vacuum simultaneously pulls blood and lymph to the distal end of the teat. In addition, the entrance of the teat canal can remain in an open position. These changes increase the possibility of penetration of pathogenic microorganisms into the udder, because the skin of the teat becomes hard and this simplifies expansion of pathogenic 
organisms which can then infiltrate the udder through the opened teat canal more easily. Repeated changes have a negative effect because they can become irreversible. DOLEŽAL et al. (1999) mentioned that a higher frequency of milking evokes lower traumatization of the teats and reduces the possibility of bacterial invasion. On the contrary, IPEMA and BENDERS (1992) found that higher milking frequency leads to greater mechanical stress of the teats and the entire udder as well. A reduction of periods between individual milkings increases the risk of teat damage, and worsening of the physiological status of the teat tissue increases the risk of udder infection.

Change in teat functionality and bacterial penetration can be affected by the vacuum of machine milking. The diameter of the distal teat end and wall thickness is significantly higher in milking with a vacuum of 50 and $40 \mathrm{kPa}$ than with a vacuum of $30 \mathrm{kPa}$. Edema persisted $30 \mathrm{~min}$ after milking with a vacuum of $50 \mathrm{kPa}$. Milking at a higher vacuum level leads to a greater long-term decline of defence mechanisms than in milking with a vacuum of $30 \mathrm{kPa}$. A vacuum of $50 \mathrm{kPa}$ increases the number of opened canals compared to $45 \mathrm{kPa}$, and the somatic cell count in milk corresponds to this fact. ZECCONI et al. (1992) described a higher level of infection in udder quarters and more frequent incidence of pathogens in the teat part of the udder in cows with a change in the size of the distal teat end after milking higher than $5 \%$. RASMUSSEN and MADSEN (2000) evaluated the effect of vacuum in a milking pipeline on the health of the mammary gland and the level of milk yield. They found that the yield and flow of milk decline when pressure in milking is $38 \mathrm{kPa}$ in comparison to $48 \mathrm{kPa}$. The milking time is longer and the number of teat extenders falling off increases simultaneously. Different vacuums in a milking pipeline have no effect on the health status of the mammary gland. The status of the teat tissue was non-significantly worse when a pressure of $38 \mathrm{kPa}$ was used. Milking with $32 \mathrm{kPa}$ pressure did not affect the level of milk yield of low-yielding cows in comparison with $42 \mathrm{kPa}$ pressure, and other traits had the same tendency in high-yielding cows as well. Pressure in milking equipment $8 \mathrm{kPa}$ higher than in milking pipelines did not increase milk yield. A short-term effect of machine milking on teat tissue manifests itself by edema, and the extent of this edema can be measured by ultrasound as shown by HOMAN and WATTIAUX (1995). A sudden change of sucking and pressing action causes greater edemas of the teats without shortening the milking time. A long-term effect is the change in the tissue of the distal teat end to a callous ring all around the orifice of the teat. This change leads to opening of the teat, thus enabling invasion of bacteria to the udder. The teat is an important barrier against the penetration of pathogens causing mastitis.

The right techniques of milking and adjustment of milking equipment guarantee good health of the teat as well as the udder. The level of vacuum in the underteat chamber is one of the main factors. VEGRICHT et al. (1995) mentioned especially the effect of its stability during milking. High-quality milking equipment should ensure minimal decline of vacuum in cows with a high intensity of milking $\left(8-101 \times \mathrm{min}^{-1}\right)$. Well-timed detachment of milking equipment from the udder is also an important factor. SCHÖN et al. (1992) reported that ordinary milking lasts about 2 min (ranging from 0 to $10 \mathrm{~min}$ ) longer than is necessary. Milking time is exceeded by about one or more min even in machines which check the intensity of milk flow, with milking equipment being removed from the udder only with a decline in milk flow to under $0.2 \mathrm{l}$ of milk per min. 
The objective of this work was to evaluate differences in external and internal proportions of traits measured closely before, immediately after and $3 \mathrm{~h}$ after milking in relation to the effect of breed, period and number of lactation.

\section{Material and methods}

Dairy cows of Holstein $(H, n=74)$ and Czech Fleckvieh $(C, n=72)$ in the 1st $(H, n=38 ; C, n=38)$ and 2 nd lactation $(H, n=36 ; C, n=34)$ were included in the data set. Differences in the external and internal parameters of the teat were evaluated. A linear description of the udder was carried out in both breeds simultaneously. Somatic cell count, milking time and daily milk yield were measured during the entire observation as well. The effect of the lactation period on the same parameters and traits was evaluated in 74 dairy cows $(H, n=40 ; C, n=34)$ during the 1st period of lactation and in 72 dairy cows $(H, n=34 ; C, n=38)$ during the 2 nd period of lactation. The measurements in the 1st period for each animal were taken up to 150 days after calving, and in the 2 nd period after 150 days.

The cows were housed in a free stable with a straw bedding and milked in an Alfa Laval milking parlour with a vacuum during the premilking stage at a level of $33 \mathrm{kPa}$ and 49 pulses $\times \mathrm{min}^{-1}$, during milking $44 \mathrm{kPa}$ and 60 pulses $\times \mathrm{min}^{-1}$ and during postmilking stage $33 \mathrm{kPa}$ and 49 pulses $\times \mathrm{min}^{-1}$. Cleaning of the udder was performed using a dry disposible paper towel. The used feeding system total mixed ration (TMR) was based on preserved components during the whole year and did not change over the year. Feed ration consisted of basic components: corn silage, alfalfa silage, straw, hay, alfalfa hay, supplement concentrate, draft, waste brad, molasses and minerals. Portion of components was in relation to daily milk production of cows in individual groups.

Teat diameter was measured with a calliper in $\mathrm{cm}$ with an accuracy of 0.1 (external diameter) in one third of the teat above the teat end. The length of the teat was also measured with a calliper with an accuracy of $0.1 \mathrm{~cm}$ from the base of the udder to the distal end of the teat.

The length of the teat canal (from the outer end to the inner end, accuracy $0.1 \mathrm{~cm}$ ), area of the teat end (area bordered by the skin line and by the perpendicular to axe of teat canal at the point of the interior end of the teat canal, accuracy $0.2 \mathrm{~cm}^{2}$ ), and wall thickness (wall thickness $1 \mathrm{~cm}$ up to teat end, accuracy $0.1 \mathrm{~cm}$ ) were measured from the axial picture recorded by ultrasound Aloka SSD500 (Aloka Co., Ltd., Tokyo, Japan) with a UST512U-7,5 MHz probe in the medial direction of the teat and in the transverse direction of the cow using a plastic bottle with water as a bath for sonography of the teat. The ultrasound was recorded as a video sequence on a VHS cassette, and a suitable picture was selected from this record in a PC using software the Pinnacle Studio 8 (Pinnacle Systems Inc., Mountain View, USA) transferring of the static pictures from the video sequence recorded from ultrasound and Lucia 4.1 software (Laboratory Imaging, s.r.o., Prague, Czech Republic) for measurement of internal parameters of the teat.

The selected traits of udder conformation were evaluated by the linear description used for the given breed during the 1st period of lactation before the beginning of individual milking. The central ligament, mammary veins, width of rear udder attachment, and rear udder attachment were evaluated by a fixed number of points in relation to methodology for these breeds. 
Milkyield, time of milking, and somatic cell count were evaluated as traits of milk performance. Milk yield was recorded from the display unit of the calibrated milking equipment with an accuracy of 0.1 I of milk. Milking time was measured by stopwatches with an accuracy of $1 \mathrm{~s}$. Measurement started with putting the teat extender on the observed teat and ended with automated detachment of the milking device from the udder. Milk samples were collected in standard sample tubes with a preserving agent from the selected quarter of the udder only. Evaluation of the somatic cell count was performed by the Fluoro-Optical-Electronic method in the State Veterinary Institute, Prague, Czech Republic.

The left front teat was observed in each dairy cow. The same teat was measured in subsequent measurements. The teat was evaluated three times: 1) closely before milking after drying of the teat; 2) immediately after milking; 3) $3 \mathrm{~h}$ after milking $\pm 15 \mathrm{~min}$. The teat was measured twice during lactation. The first measurement was made up to 150 days of lactation (the 1st period) and the second after 150 days (the 2nd period).

The basic statistical parameters - minimum (min), maximum (max), least square mean $(\mu+a)$, and standard error (SE) were calculated for all the observed traits before, immediately after, and $3 \mathrm{~h}$ after milking. The total number of observations $(\mathrm{n})$ is presented in the tables describing the results.

The statistically significant differences between the average values of observed parameters were determined in relation to the effect of breed and period of lactation.

The dataset was analysed by ANOVA through the statistical program SAS STAT 9.1 - GLM (SAS Institute 2001).

Evaluation was performed using the following general linear model:

$$
Y_{i j k l}=\mu+\text { BREED }_{i}+\text { PERIOD }_{j}+\text { LACTATION }_{k}+e_{i j k l}
$$

where $Y_{i j k l}$ is the observed value of the parameter as a dependent variable (diameter of the teat, length of the teat, length of the teat canal, area of the teat end, and wall thickness before, immediately after, and $3 \mathrm{~h}$ after milking; the suspensory ligament, the mammary veins, the width of the rear attachment, the rear udder attachment, the number of somatic cells per $\mathrm{ml}$ of milk, the length of milking, and daily milk yield), $\mu$ is the average value of dependent variable, $B R E E D_{i}$ is the fixed effect of $i$-breed ( $i=$ Czech Fleckvieh, $\mathrm{n}=72$; Holstein, $\mathrm{n}=74), P E R I O D_{j}$ is the fixed effect of $j$-period of lactation ( $j=1$ st period - up to 150 days of lactation, $\mathrm{n}=74$, 2nd period - above 150 days of lactation, $\mathrm{n}=72$ ), LACTATION $_{k}$ is the fixed effect of $k$-lactation ( $k=1$ st lactation, $n=76,2$ nd lactation, $n=70), e_{i j k l}$ is the residual effects (random error).

Differences between estimated variables were tested at the levels of significance $P<0.05$ $\left({ }^{*}, \mathrm{a}\right), P<0.01(* *, \mathrm{~b})$, and $P<0.001\left({ }^{* *}, \mathrm{c}\right)$.

Relative changes of external and internal parameters of the teat between measurements immediately after and $3 \mathrm{~h}$ after milking were calculated in accordance with the equation:

$$
R_{i}(\%)=\Sigma_{\text {in }}\left(Y_{\text {in }} \text { resp. } Z_{\text {in }} / X_{\text {in }}\right) / n \cdot 100
$$

where $X_{i n}$ is the value of $i$-trait in n-cow closely before milking, $Y_{i n}$-value of $i$-trait in $n$-cow immediately after milking, $Z_{i n}$-value of $i$-trait in $n$-cow $3 \mathrm{~h}$ after calving, $i$-observed parameters of teat-diameter of teat, length of teat, length of teat canal, area of teat end, and wall thickness, $n$-number of cows in the group. 


\section{Results and discussion}

The proportions of teats, traits of udder linear description and daily milk yield determined in relation to the breed of cows are presented in Table 1. Selected traits of the udder belong among functional traits affecting the length of productive life (MÉSZÁROS et al. 2008). The values of the external proportions of the teat were higher in Czech Fleckvieh cows (C) in comparison with Holstein (H). Differences in teat diameter $3 \mathrm{~h}$ after milking, length of the teat closely before and $3 \mathrm{~h}$ after milking were statistically significant between these breeds $(P<0.001)$. The teat was $0.74 \mathrm{~cm}$ longer before milking in the $C$ cows $(P<0.001)$, $0.73 \mathrm{~cm}$ immediately after $(P<0.05)$, and $0.85 \mathrm{~cm} 3 \mathrm{~h}$ after milking $(P<0.001)$. GLEESON and CALLAGHAN (1998) recorded the length of the teat before milking as $5.25 \mathrm{~cm}$ and $6.11 \mathrm{~cm}$ after milking. In the present study was measured $5.37 \mathrm{~cm}$ before, $5.63 \mathrm{~cm}$ immediately after, and $5.13 \mathrm{~cm} 3 \mathrm{~h}$ after milking in the group of $\mathrm{H}$ cows, while in the $\mathrm{C}$ cows the length of the teat was $6.11 \mathrm{~cm}$ before, $6.36 \mathrm{~cm}$ immediately after, and $5.98 \mathrm{~cm} 3 \mathrm{~h}$ after milking. Teat diameter decreased immediately after milking from 0.14 to $0.15 \mathrm{~cm}$ in both breeds $(P<0.05)$. A slower decline in relative teat diameter $3 \mathrm{~h}$ after milking to $97.4 \%$ of that before milking was found in breed C. This fact is presented in Table 2. Changes in teat proportions measured between the values before and $3 \mathrm{~h}$ after milking and between those immediately after and $3 \mathrm{~h}$ after milking in breed $\mathrm{H}$, and between the 1st and the $3 \mathrm{rd}$ measurement in breed $\mathrm{C}$ were statistically significant $(P<0.001)$. Relative changes in the diameter of the teat between the $C$ and $\mathrm{H}$ cows were significant between measurements before and $3 \mathrm{~h}$ after milking $(P<0.05)$. Teat diameter was reduced more in the $\mathrm{H}$ breed. The length of the teat immediately after milking was extended in both breeds, but was shorter $3 \mathrm{~h}$ after milking than closely before milking. A significant difference $(P<0.001)$ between the values measured immediately after and $3 \mathrm{~h}$ after milking was detected only in the $\mathrm{H}$ group. Relative changes of teat length were very similar and non-significant in both breeds. The teat length extended to $104.5 \%$ immediately after milking in the C cows and to $106.4 \%$ in the group of $\mathrm{H}$ cows. KLEIN et al. (2005) observed the length of the teat canal by ultrasound in four breeds - Brown Swiss, Simental, crossbreeds Simmental $\times$ Czech Fleckvieh, and Holstein. The present findings did not differ significantly. In agreement with the results of WEIS et al. (2004), in the present study was confirmed the differences in the length of the teat canal and teat proportions in individual breeds. The length of the teat $3 \mathrm{~h}$ after milking was $99.1 \%$ of that before milking in the $\mathrm{C}$ cows and $96.8 \%$ in the $\mathrm{H}$ breed.

The length of the teat canal measured via ultrasound was $1.42 \mathrm{~cm}$ before milking, $1.68 \mathrm{~cm}$ immediately after, and $1.52 \mathrm{~cm} 3 \mathrm{~h}$ after milking in the $\mathrm{C}$ breed. The average length of the teat canal in the $\mathrm{H}$ cows was $1.35 \mathrm{~cm}$ before, $1.50 \mathrm{~cm}$ immediately after, and $1.39 \mathrm{~cm} 3 \mathrm{~h}$ after milking. Interbreed differences were significant immediately after $(P<0.01)$ and $3 \mathrm{~h}$ after milking $(P<0.05)$. GLEESON and O'CALLAGHAN (1998) described the length of the teat canal before milking at the level of $1.21 \mathrm{~cm}$, and PAULRUD (2005) from 0.30 to $1.80 \mathrm{~cm}$.

The most significant differences in internal proportions were determined in both breeds within those values measured before and immediately after milking. Differences in the teat canal length were significant at level $P<0.01$ in the group of $C$ cows between the 1 st and the 2nd measurement and at level $P<0.05$ between the 2nd and the 3rd measurement, while these differences were significant at levels $P<0.001$ and $P<0.01$ in the $\mathrm{H}$ cows. The dynamics 
of changes in the length of the teat canal demonstrated extension by $20 \%$ in the $\mathrm{C}$ breed and by $14 \%$ in the $\mathrm{H}$ cows. A sudden restoration of the initial length by $11 \%$ was detected $3 \mathrm{~h}$ after milking in the cows of the $\mathrm{C}$ breed; however, the teat canal did not reach the initial length during $3 \mathrm{~h}$ after milking (+9\%). Restoration of the length of the teat canal $3 \mathrm{~h}$ after milking was slower, by $5.7 \%$ only, in the group of $\mathrm{H}$ cows, but the initial size was not restored (+8.3\%).

Table 1

Evaluated traits of udder and teat conformation, and milk production according to breed Merkmale des Euters und der Zitzen sowie die Milchproduktion der Rasse Tschechisches Fleckvieh und Holstein

\begin{tabular}{|c|c|c|c|c|c|c|c|c|c|}
\hline & \multicolumn{4}{|c|}{ Czech Fleckvieh $(n=72)$} & \multicolumn{4}{|c|}{ Holstein $(n=74)$} & \multirow[t]{2}{*}{$P$} \\
\hline & $\min$ & $\max$ & $\mu+a$ & SE & $\min$ & $\max$ & $\mu+a$ & SE & \\
\hline \multicolumn{10}{|c|}{ External proportions } \\
\hline \multicolumn{10}{|c|}{$\mathrm{DT}, \mathrm{cm}$} \\
\hline 1st M. & 2.1 & 3.5 & $2.64^{\mathrm{a}, \mathrm{c}}$ & 0.29 & 1.9 & 3.6 & $2.51^{\mathrm{a}, \mathrm{c}}$ & 0.35 & \\
\hline 2nd M. & 2.0 & 2.9 & $2.49^{\mathrm{a}}$ & 0.23 & 1.9 & 3.2 & $2.37^{a, c}$ & 0.26 & $*$ \\
\hline 3rd M. & 2.0 & 3.3 & $2.55^{c}$ & 0.31 & 1.8 & 3.3 & $2.32^{c}$ & 0.30 & $* * *$ \\
\hline \multicolumn{10}{|l|}{$\mathrm{LT}, \mathrm{cm}$} \\
\hline 1st M. & 4.0 & 8.0 & 6.11 & 0.94 & 3.2 & 9.4 & 5.37 & 1.14 & $* * *$ \\
\hline 2nd M. & 4.5 & 9.6 & 6.36 & 0.91 & 3.9 & 8.2 & $5.63^{c}$ & 0.94 & * \\
\hline 3rd M. & 4.5 & 7.6 & 5.98 & 0.79 & 3.2 & 8.0 & $5.13^{c}$ & 0.88 & $* * *$ \\
\hline \multicolumn{10}{|l|}{ Int. proportions } \\
\hline \multicolumn{10}{|l|}{$\mathrm{LTC}, \mathrm{cm}$} \\
\hline 1st M. & 1.0 & 1.8 & $1.42^{c}$ & 0.24 & 0.9 & 1.9 & $1.35^{c}$ & 0.25 & \\
\hline 2nd M. & 1.2 & 2.2 & $1.68^{\mathrm{a}, \mathrm{c}}$ & 0.30 & 1.1 & 2.0 & $1.50^{\mathrm{b}, \mathrm{c}}$ & 0.21 & ** \\
\hline 3rd M. & 1.1 & 2.0 & $1.52^{\mathrm{a}}$ & 0.26 & 0.9 & 1.9 & $1.39^{b}$ & 0.20 & $*$ \\
\hline \multicolumn{10}{|l|}{ ATE, $\mathrm{cm}^{2}$} \\
\hline 1st M. & 1.6 & 4.1 & $2.70^{\mathrm{b}}$ & 0.65 & 1.3 & 3.4 & $2.19^{c}$ & 0.56 & $* * *$ \\
\hline 2nd M. & 1.9 & 4.6 & $3.19^{a, b}$ & 0.78 & 1.7 & 3.94 & $2.54^{\mathrm{b}, \mathrm{c}}$ & 0.50 & $* * *$ \\
\hline 3rd M. & 1.8 & 4.1 & $2.83^{\mathrm{a}}$ & 0.65 & 1.2 & 3.24 & $2.26^{b}$ & 0.46 & $* * *$ \\
\hline \multicolumn{10}{|l|}{ WT, cm } \\
\hline 1st M. & 0.6 & 1.0 & $0.79^{a}$ & 0.11 & 0.5 & 1.2 & $0.74^{c}$ & 0.15 & \\
\hline 2nd M. & 0.8 & 1.0 & $0.90^{\mathrm{a}}$ & 0.07 & 0.6 & 1.4 & $0.85^{c}$ & 0.13 & \\
\hline 3rd M. & 0.8 & 0.8 & 0.86 & 0.05 & 0.6 & 1.1 & $0.78^{c}$ & 0.12 & $* * *$ \\
\hline \multicolumn{10}{|c|}{ Linear description } \\
\hline SL & 1 & 7 & 4.5 & 1.77 & 1 & 7 & 5.0 & 1.47 & \\
\hline MV & 1 & 6 & 3.5 & 1.52 & 1 & 8 & 4.2 & 1.48 & $*$ \\
\hline WRA & 3 & 8 & 5.6 & 1.25 & 1 & 8 & 5.7 & 1.18 & \\
\hline RUA & 2 & 8 & 4.8 & 1.71 & 3 & 9 & 5.5 & 1.15 & ** \\
\hline \multicolumn{10}{|l|}{ Milk production } \\
\hline NSC, $1000 / \mathrm{ml}$ & 10 & 1238 & 181.1 & 320.0 & 2 & 5336 & 380.2 & 1208.8 & \\
\hline $\mathrm{LM}, \mathrm{s}$ & 183 & 911 & 359.0 & 98.25 & 170 & 977 & 375.1 & 113.07 & \\
\hline DMY, I & 6.1 & 32.5 & 14.14 & 6.79 & 3.6 & 28.8 & 13.96 & 4.079 & \\
\hline
\end{tabular}

DT diameter of teat, LT length of teat, Int. proportions internal proportions, LTC length of teat canal, ATE area of teat end, WT wall thickness, SL suspensory ligament, MV mammary veins, WRA width of rear attachment, RUA rear udder attachment, NSC number of somatic cells, LM length of milking, DMY daily milk yield, 1st M. 1. measurement - before milking, 2nd M. after milking, 3rd M. 3 h after milking, $P<0.05\left({ }^{*}, a\right), P<0.01(* *, b), P<0.001\left({ }^{* *}, c\right), a, b, c$ statistical significances of differences among individual rows (measurements), $P$ statistical significances of differences among individual columns (breeds) 
Table 2

Relative changes in values between the 1 st and 2 nd or the 1 st and 3 rd measurement of evaluated traits in relation to breed of animals

Die relative Änderung der Euter- und Zitzenmerkmale zwischen der ersten und zweiten, oder ersten und dritten Messung nach Rassen

\begin{tabular}{|c|c|c|}
\hline & Czech Fleckvieh $(n=72)$ & Holstein $(n=74)$ \\
\hline \multicolumn{3}{|l|}{ External proportions } \\
\hline Teat diameter 2/1, cm & $95.1 \%$ & $95.4 \%$ \\
\hline Teat diameter $3 / 1, \mathrm{~cm}$ & $97.4 \%$ & $93.1 \%$ \\
\hline Teat length $2 / 1, \mathrm{~cm}$ & $104.5 \%$ & $106.4 \%$ \\
\hline Teat length $3 / 1, \mathrm{~cm}$ & $99.1 \%$ & $96.8 \%$ \\
\hline \multicolumn{3}{|l|}{ Internal proportions } \\
\hline Length of teat canal $2 / 1, \mathrm{~cm}$ & $120.0 \%$ & $113.9 \%$ \\
\hline Length of teat canal $3 / 1, \mathrm{~cm}$ & $109.0 \%$ & $108.2 \%$ \\
\hline Area of teat end $2 / 1, \mathrm{~cm}^{2}$ & $121.9 \%$ & $121.7 \%$ \\
\hline Area of teat end $3 / 1, \mathrm{~cm}^{2}$ & $107.6 \%$ & $110.9 \%$ \\
\hline Wall thickness 2/1, cm & $115.6 \%$ & $118.0 \%$ \\
\hline Wall thickness $3 / 1, \mathrm{~cm}$ & $112.7 \%$ & $111.9 \%$ \\
\hline
\end{tabular}

1 first measurement - before milking, 2 second measurement - after milking, 3 third measurement - $3 \mathrm{~h}$ after milking, 2/1 relative changes in values between the 2 nd and the 1 st measurement, $3 / 1$ relative changes in values between the 3rd and the 1st measurement

The area of the teat end differed significantly between the evaluated breeds in all three measurements $(P<0.001)$. Significant differences in the area of the teat end were determined between the 1st and the 2nd measurements $(P<0.01)$ and between the 2 nd and the $3 \mathrm{rd}$ measurements $(P<0.05)$ in the $C$ cows, respectively at levels $P<0.001$ and $P<0.01$ in the cows of the $\mathrm{H}$ breed. Enlargement of the teat end area was comparable, $21.9 \%$ in group $\mathrm{C}$ and $21.7 \%$ in group $\mathrm{H}$. However, the area remained enlarged $3 \mathrm{~h}$ after milking differently, in the $\mathrm{C}$ breed by $7.6 \%$ and by $10.9 \%$ in the $\mathrm{H}$ cows. Relatively fast restoration of the teat end area to its initial size demonstrates good health condition of the teats in cows of both breeds as well as proper milking management, according to the findings of DOLEŽAL et al. (2000), VEGRICHT et al. (1995), and NEIJENHUIS et al. (2000). NEIJENHUIS et al. (2001) called attention to the importance of the teat end as a barrier against infiltration of infection into the udder in the case of incorrect milking procedures.

The wall thickness was strengthened in the $C$ cows (+15.6\%) during the 2 nd measurement immediately after milking in comparison with the 1st measurement before milking $(P<0.05)$. Significant differences in the wall thickness were detected in the $\mathrm{H}$ cows between the $1 \mathrm{st}$ and the 2 nd measurements $(+18 \% ; P<0.001)$ and between the 2 nd and the 3 rd measurements. Three hours after milking the wall remained $12.7 \%$ thicker in the C cows and by $13.41 \%$ thicker in the $\mathrm{H}$ breed. Interbreed differences were mentioned in the findings of KLEIN et al. (2005). In our observation, significant differences in the wall thickness between both breeds were determined $3 \mathrm{~h}$ after milking only $(P<0.001)$.

Values of the linear description of udder traits, which was performed during the 1st period of lactation, are presented in Table 1. Better values of the selected linear traits were detected in the $\mathrm{H}$ breed compared to the $\mathrm{C}$ breed. Significant differences in favour of the $\mathrm{H}$ cows were determined in the width of rear udder attachment $(P<0.01)$ and the mammary veins $(P<0.05)$. Evaluation of the udder by linear description indicates that the mammary system of both 
breeds corresponds to their breeding standards. Similar findings were presented by BOUŠKA et al. (1999). BOUŠKA et al. (2006) demonstrated that the objective of breeding systems is to maximize the overall herd profit, and therefore they evaluated positively the inclusion of udder traits in the total selection indexes used in the Czech Republic as reported by ŠAFUS et al. (2005). The selection is made according to hereditary disposition, which is defined by the breeding value of selected traits (BEZDÍČEK et al. 2008).

Non-significant interbreed differences were found at the time of milking and in the daily milk yield. The average milk yield was $14.4 \mathrm{I}$ and the milking time represented $359 \mathrm{~s}$ in the cows of breed $\mathrm{C}$ and $13.96 \mathrm{I}$, resp. $380 \mathrm{~s}$ in breed $\mathrm{H}$.

The average values for somatic cell count (SCC) in the milk of the observed breeds were 181100 in one ml of milk in breed C and 380200 SCC in the H cows. However, the difference was not statistically significant. PINĎÁK et al. (1993) stated the range from 200000 to 300000 as a high risk for the occurrence of mastitis, while DOLEŽAL et al. (1999) presented the average somatic cell count in cows from the 1st to the 4th lactation in the range from 212000 to 264000 in one ml of milk. NĚMCOVÁ et al. (2007) found that low somatic cell score appears to be associated with the longer teats of Holstein dairy cows. According to KVAPILÍK et al. (2006), the data set of the $C$ cows belongs to the best $18 \%$ of the entire population, while it is $9.4 \%$ from all $\mathrm{H}$ dairy cows bred in the Czech Republic. KOÇ and KIZILKAYA (2009) reported similar difference in SCC between evaluated breeds and they interpreted this difference as result of different resistance mechanisms against mastitis, different morphological conformations of udders, and different milk yields of these breeds.

In the present study was observed cows during the 1st and the 2nd lactation and detected non-significant differences between these lactations. SAWA and KRĘŻEL-CZEPEK (2009) mentioned that the 1st lactation is considered as a test lactation because the cow's body is still developing. Values of the evaluated proportions of the teat and traits of the milk performance in relation to the period of lactation are described in Tables 3 and 4. Higher values of the external proportions of the teat were measured in the 2nd period of lactation except for the diameter of the teat closely before milking. A significant difference was detected only in the teat diameter $3 \mathrm{~h}$ after milking $(P<0.05)$. The internal proportions of the teat were always significantly higher $(P<0.05-0.001)$ in the 2 nd period of lactation compared to the 1 st period. The prolongation of the teat canal by $0.15 \mathrm{~cm}$ closely before $(P<0.01)$, by $0.16 \mathrm{~cm}$ immediately after $(P<0.001)$, and by $0.13 \mathrm{~cm} 3 \mathrm{~h}$ after milking $(P<0.01)$ was measured in the 2 nd period of lactation. The teat end area before milking showed $2.14 \mathrm{~cm}^{2}$ in the 1 st period, while $2.47 \mathrm{~cm}^{2}$ during the $2 \mathrm{nd}$ period, and this difference was significant $(P<0.01)$. The difference measured in the teat end area immediately after milking was smaller and significant $(P<0.05)$, while the difference detected $3 \mathrm{~h}$ after milking was more significant $(P<0.01)$.

The same tendency was observed in the wall thickness, when the values were higher during the 2nd period of lactation, but all differences were non-significant. NEIJENHUISE et al. (2000) discussed the long-term effect of milking on the teat tissue, which can prolong the time for regeneration of the teat.

Differences in the average milk yield were non-significant, contrary to the findings of KOCAK and EKÍZ (2008), which reported significant differences in milk production according to the period of lactation. Somatic cell count was lower in the 2nd period, but non-significantly with respect to a higher level of variance. The time of milking was non- 
significantly shorter during the 2nd period, although the daily milk yield was practically the same.

The significances of differences between the values of the external and internal proportions of the teat, which were measured closely before (1st), immediately after (2nd) and $3 \mathrm{~h}$ after milking (3rd), are described in Table 3. Statistically significant differences were found in almost all measurements of the observed traits of the teat between the 1st and the 2nd period of lactation $(P<0.05-0.001)$.

Table 3

Evaluated traits of udder and teat conformation, and milk production according to period of lactation Merkmale des Euters und der Zitzen sowie die Milchproduktion in der ersten und zweiten Laktationsperiode

\begin{tabular}{|c|c|c|c|c|c|c|c|c|c|}
\hline & & 1st period & - to 150 days & $(n=74)$ & 2nd & period - $a b c$ & ve 150 days & $(n=72)$ & $P$ \\
\hline & $\mathrm{m}$ & in $\quad m$ & $a x \quad \mu+a$ & SE & $\min$ & $\max$ & $\mu+a$ & SE & \\
\hline External propor & tions & & & & & & & & \\
\hline $\mathrm{DT}, \mathrm{cm}$ & & & & & & & & & \\
\hline 1st M. & 1.9 & 3.5 & $2.54^{c}$ & 0.38 & 2.0 & 3.6 & $2.54^{\mathrm{a}, \mathrm{b}}$ & 0.29 & \\
\hline 2nd M. & 1.9 & 3.0 & $2.37^{c}$ & 0.23 & 1.9 & 3.2 & $2.44^{\mathrm{a}}$ & 0.28 & \\
\hline 3rd M. & 1.9 & 3.1 & $2.33^{c}$ & 0.30 & 1.8 & 3.3 & $2.44^{b}$ & 0.33 & $*$ \\
\hline $\mathrm{LT}, \mathrm{cm}$ & & & & & & & & & \\
\hline 1st M. & 3.5 & 9.4 & 5.51 & 1.23 & 3.2 & 8.0 & 5.62 & 1.04 & \\
\hline 2nd M. & 4.0 & 8.2 & $5.71^{b}$ & 0.91 & 3.9 & 9.6 & $5.96^{\mathrm{a}}$ & 1.04 & \\
\hline 3rd M. & 3.2 & 8.0 & $5.22^{\mathrm{b}}$ & 0.94 & 3.3 & 7.7 & $5.51^{\mathrm{a}}$ & 0.90 & \\
\hline Int. proportions & & & & & & & & & \\
\hline $\mathrm{LTC}, \mathrm{cm}$ & & & & & & & & & \\
\hline 1st M. & 0.9 & 1.8 & $1.30^{c}$ & 0.21 & 0.9 & 1.9 & $1.45^{c}$ & 0.27 & ** \\
\hline 2nd M. & 1.1 & 2.1 & $1.47^{\mathrm{a}, \mathrm{c}}$ & 0.21 & 1.1 & 2.2 & $1.63^{\mathrm{a}, \mathrm{c}}$ & 0.25 & $* * *$ \\
\hline 3rd M. & 0.9 & 1.9 & $1.38^{\mathrm{a}}$ & 0.18 & 1.0 & 2.0 & $1.51^{\mathrm{a}}$ & 0.27 & $* *$ \\
\hline ATE, $\mathrm{cm}^{2}$ & & & & & & & & & \\
\hline 1st M. & 1.3 & 3.3 & $2.14^{c}$ & 0.52 & 1.3 & 4.1 & $2.47^{b}$ & 0.67 & ** \\
\hline 2nd M. & 1.7 & 4.4 & $2.55^{\mathrm{b}, \mathrm{c}}$ & 0.58 & 1.8 & 4.6 & $2.83^{b}$ & 0.63 & * \\
\hline 3rd M. & 1.3 & 3.5 & $2.26^{\mathrm{b}}$ & 0.48 & 1.6 & 4.1 & 2.63 & 0.64 & $* *$ \\
\hline WT, cm & & & & & & & & & \\
\hline 1st M. & 0.5 & 1.0 & $0.73^{\mathrm{a}, \mathrm{c}}$ & 0.13 & 0.5 & 1.2 & $0.77^{c}$ & 0.16 & \\
\hline 2nd M. & 0.6 & 1.1 & $0.85^{\mathrm{b}, \mathrm{c}}$ & 0.10 & 0.6 & 1.4 & $0.87^{a, c}$ & 0.14 & \\
\hline $3 r d M$. & 0.6 & 1.1 & $0.79^{a, b}$ & 0.12 & 0.6 & 0.9 & $0.80^{\mathrm{a}}$ & 0.10 & \\
\hline Milk production & & & & & & & & & \\
\hline $\mathrm{NSC}, 1000 / \mathrm{ml}$ & 2 & 5336 & 265.7 & 1019.0 & 16 & 1238 & 260.1 & 365.7 & \\
\hline $\mathrm{LM}, \mathrm{s}$ & 217 & 624 & 396.7 & 91.24 & 170 & 977 & 351.0 & 130.5 & \\
\hline DMY, I & 5.1 & 22.8 & 13.92 & 4.324 & 3.6 & 32.5 & 14.08 & 5.434 & \\
\hline
\end{tabular}

Ext.proportions external proportions, DT diameter of teat, LTlength of teat, Int.proportionsinternal proportions, LTC length of teat canal, ATE area of teat end, WT wall thickness, NSC number of somatic cells, LM length of milking, DMY daily milk yield, 1st M. before milking, 2nd M. after milking, 3rd M. $3 \mathrm{~h}$ after milking, $P<0.05\left({ }^{*}, \mathrm{a}\right), P<0.01 \quad(* *$, b), $P<0.001$ (***, c), a, b, c statistical significances of differences among individual rows (measurements), $P$ statistical significances of differences among groups in individual columns (periods) 
Table 4

Relative changes in values between the 1st and $2 \mathrm{nd}$ or the $1 \mathrm{st}$ and $3 \mathrm{rd}$ measurement of evaluated traits in relation to the period of lactation

Die relative Änderung der beobachteten Zitzenmerkmale zwischen der ersten und zweiten, oder ersten und dritten Messung - erste und zweite Laktationsperiode

\begin{tabular}{lcc}
\hline & 1st period - to 150 days $(\mathrm{n}=74)$ & 2nd period - above 150 days $(\mathrm{n}=72)$ \\
\hline External proportions & & \\
Teat diameter 2/1, cm & $94.3 \%$ & $96.4 \%$ \\
Teat diameter 3/1, cm & $92.3 \%$ & $96.3 \%$ \\
Teat length 2/1, cm & $105.2 \%$ & $106.7 \%$ \\
Teat length 3/1, cm & $96.2 \%$ & $98.8 \%$ \\
Internal proportions & & \\
Length of teat canal 2/1, cm & $116.2 \%$ & $113.4 \%$ \\
Length of teat canal 3/1, cm & $108.5 \%$ & $108.1 \%$ \\
Area of teat end 2/1, cm & $124.1 \%$ & $118.4 \%$ \\
Area of teat end 3/1, cm & $110.2 \%$ & $110.0 \%$ \\
Wall thickness 2/1, cm & $119.7 \%$ & $114.6 \%$ \\
Wall thickness 3/1, cm & $111.9 \%$ & $112.4 \%$ \\
\hline
\end{tabular}

1 first measurement - before milking, 2 second measurement - after milking, 3 third measurement - $3 \mathrm{~h}$ after milking, 2/1 relative changes in values between the 2 nd and the 1 st measurement, 3/1 relative changes in values between the 3rd and the 1st measurement

The relative changes of values between the 1st and the $2 \mathrm{nd}$, and between the 1 st and the 3rd measurements are presented in Table 4 . The value of the teat diameter immediately after milking decreased more significantly (94.3\%) in the 1st period of lactation than in the 2nd period $(96.4 \%)$ with respect to the initial size $(P<0.001)$. A significant decline of this parameter $(P<0.001)$ was subsequently found $3 \mathrm{~h}$ after milking, especially in the 1 st period $(92.3 \%)$ in comparison to the 2 nd period (96.3\%).

The length of the teat was prolonged to $105.2 \%$ and to $106.7 \%$ immediately after milking in the 1 st, respectively in the 2 nd period $(P<0.001)$. However, the values represented $96.2 \%$, respectively $98.8 \% 3 \mathrm{~h}$ after milking. The values of all internal proportions of the teat increased immediately after milking, and no value returned to the initial size during $3 \mathrm{~h}$ after milking. Although the relative changes of the observed traits between the 1st and the 2nd period of lactation were non-significant, we found a tendency of teat stability to decline during milking and in its capability to reach its initial size as well. These findings are in agreement with the results of NEIJENHUIS et al. (2000).

In conclusion, significant interbreed differences in external as well as internal proportions of teats and udder traits of linear description, in relation to measurement closely before, immediately after, and $3 \mathrm{~h}$ after milking were determined. Significant relative changes were also detected during the entire observation in both breeds. These results indicate different tolerance of teats to machine milking between the evaluated breeds and document the higher risk of physiological disturbances of the mammary system in Holstein cows. Significant differences in external and internal proportions were also determined in relation to the period of lactation. Long-term milking burdens the udder and its functionality. These facts emphasized the necessity of proper milking management and adjustment of milking machines. 


\section{Acknowledgements}

This research was funded by the Ministry of Education, Youth, and Sports of the Czech Republic (Project No. MSM 6046070901) and by the Ministry of Agriculture of the Czech Republic (Project No. NAZV QH91270).

We thank Mrs. Lois Russell for her editorial help with this manuscript.

\section{References}

Bezdíček J, Šubrt J, Filipčík R (2008) The effect of inbreeding on milk traits in Holstein cattle in the Czech Republic. Arch Tierz 51, 415-25

Bouška J, Štípková M, Bartoň L, Jirmánek M (1999) Genetic parameter estimates for linearly described traits and conformation evaluation of Czech Pied cattle. Czech J Anim Sci 44, 289-93 [in Czech]

Bouška J, Vacek M, Štípková M, Němcová E, Pytloun P (2006) The relationship between conformations of dams and daughters in Czech Holsteins. Czech J Anim Sci 51, 236-40

Doležal O, Gregoriadesová J, Abramson S M (1999) Effect of milking frequency on health, production and economy of milk. Czech J Anim Sci 44, 26-7 [in Czech]

Doležal O, Hlásný J, Jílek F, Hanuš O, Vegricht J, Pytloun J, Matouš E, Kvapilík J (2000) Milk, milking, milking parlours. Ing. František Savov - AGROSPOJ Praha, Czech Republic [in Czech]

Gleeson DE, O'Callaghan EU (1998) The effect of machine milking on teat-tissue reaction using ultrasonic analysis. Proceedings of the 37th National Mastitis Concill, 28-30 January 1998, St. Louis, Missouri, 254-5

Homan EJ, Wattiaux MA (1995) Technical Dairy Guide: Lactation and Milking. 2nd Edition, University of Wisconsin, USA

Ipema AH, Benders E (1992) Production, duration of machine-milking and teat quality of dairy cows milked 2,3 or 4 times daily with variable intervals. Proceedings of the International Symposium on Prospects for Automatic Milking, 23-25 November 1992, Wageningen, Netherlands, 244-52

Klein D, Flöck M, Kholl JL, Franz S, Stüger HP, Baumgartner W (2005) Ultrasonographic measurement of the bovine teat: breed differences and the significance of the measurements for udder health. J Dairy Res 72, 296-302

Koç A, Kizilkaya K (2009) Some factors influencing milk somatic cell count of Holstein Friesian and Brown Swiss cows under the Mediterranean climatic conditions. Arch Tierz 52, 124-33

Koçak Ö, Ekíz B (2008) Comparison of different lactation curve models in Holstein cows raised on a farm in the south-eastern Anatolia region. Arch Tierz 51, 329-37

Kvapilík J, Růžička Z, Bucek P (2006) Annual Report of Cattle Breeding in the Czech Republic. ČMSCH, a.s., Praha, Czech Republic [in Czech]

Mészáros G, Fuerst Ch, Fuerst-Waltl B, Kadlečík O, Kasarda R, Sölkner J (2008) Genetic evaluation for length of productive life in Slovak Pinzgau cattle. Arch Tierz 51, 438-48

Neijenhuis F, Barkema HW, Noordhuizen JP (2000) Clasification and Longitudinal Examination of Callused Teat Ends in Dairy Cows. J Dairy Sci 83, 2795-804

Neijenhuis F, Klungel GH, Hogeveen $\mathrm{H}$ (2001) Recovery of cow teats after milking as determined by ultrasonographic scanning. J Dairy Sci 84, 2599-606

Němcová E, Štípková M, Zavadilová L, Bouška J, Vacek M (2007) The relationship between somatic cell count, milk production and six linearly scored type traits in Holstein cows. Czech J Anim Sci 52, 437-46

Paulrud CO (2005) Basic Concept of the Bovine Teat Canal. Vet Research Commun 29, 215-45

Pindák J, Vetýška J (1993) Basic instructions for breeding and feeding of cattle. VUCHS Rapotín, 1-150, [in Czech]

Rasmussen MD, Madsen NP (2000) Effect of Milkline Vacuum, Pulsator Airline Vacuum and Cluster Weight on Milk Yield, Teat Condition and Udder Health. J Dairy Sci 83, 77-84 
SAS Institute (2001) SAS v 8.02 (TS2MO). SAS Institute Inc., Cary, NC, USA

Sawa A, Krężel-Czopek S (2009) Effect of first lactation milk yield on efficiency of cows in herds with different production levels. Arch Tierz 52, 7-14

Schön H, Artmann R, Worstorff H (1992) The automation of milking as a key issue in future oriented dairy farming. Proceedings of the International Symposium on Prospects for AutomaticMilking, 23-25 November 1992, Wageningen, Netherlands, 7-22

Šafus P, Štípková M, Stádník L, Přibyl J, Čermák V (2005) Sub-indexes for bulls of Holstein breed in the Czech Republic. Czech J Anim Sci 50, 254-65

Twardon J, Dzieciol M, Nizanski W, Dejneka GJ (2001) Use of ultrasonography in diagnosis of the teats disorders. Medycyna Weterynaryjna 57, 874-5 [in Polish]

Vegricht J, Svoboda J, Pechač F (1995) Effective technics and technological systems for dairy cows. Proceedings of papers "Modernization of technological systems in dairy cows breeding", 20. September, Rapotín, Czech Republic, 125-38 [in Czech]

Weiss D, Weinfurtner M, Bruckmaier RM (2004) Teat anatomy and its relationship with quarter and milk flow characteristics in dairy cows. J Dairy Sci 87, 3280-9

Zecconi A, Hamann J, Bronco V, Ruffo G (1992) Machine-induced teat tissue reactions and infection risk in dairy herd free of contagious mastitis pathogens. J Dairy Sci 59, 265-71

Received 21 October 2009, accepted 12 August 2010.

Corresponding author:

LUDĚK STÁDNÍK

email: stadnik@af.czu.cz

Department of Animal Husbandry, Faculty of Agrobiology, Food and Natural Resources, Czech University of Life Sciences Prague, Kamýcká 129, 165 21, Prague 6 - Suchdol, Czech Republic 